J. Product. \& Dev., 15(2): 223-235 (2010)

\title{
PHYTOHORMONES SCREENING OF Drosera capensis AS INSECTIVOROUS PLANTS AND ITS EXTRACT EFFECT ON in- vitro GROWTH AND DEVELOPMENT OF DATE PALM (Phoenix dactylifera cv. Bartamouda)
}

\author{
Ibrahim A .Ibrahim*; Hamdy A. Emara*; Abdel-Moneam M. El-Banna ${ }^{\text {** }}$ \\ and Ibrahim M. Shams El-Din** \\ * Plant Biotechnology Department, Genetic Engineering and Biotechnology \\ Research Institute (GEBRI), Minufiya University. \\ ** Central Laboratory of Date Palm Research and Development, \\ Agricultural Research Center, Giza, Egypt.
}

\section{ABSTRACT}

Carnivorous or insectivorous plants belong to several botanical families, the most important of them is Droseraceae, which includes Drosera plants. Some economic substances are extracted from Drosera. Tissue culture technique provides the best way to obtain as high and clean quantity as possible of the biomass needed to obtain these substances. This study aimed to evaluate the Drosera capensis content from phytohormones. Also studying the effect of Drosera capensis leaf and root extracts as plant growth substances on in-vitro growth of one of the most important crops that is Phoenix dactylifera cv. Bartamouda.

The amounts of phytohormones in this plant $\left(\mathrm{mg}_{100 \mathrm{~g}^{-1}}\right.$ fresh weight) were as following: Indole acetic acid in leaf was 2.055, while in case of root was 2.291. Zeatine in leaf was 1.609, while in case of root was 0.418. Other cytokinins in leaf was 18.791, while in case of root was 1.003. Gibberellic acid in leaf was 70.938, while in case of root was 86.59. Abscissic acid in leaf was 0.500, while in case of root was 0.158. Concentrations of the extract of Drosera capensis leaves and roots were applied at different ratios in in-vitro experiments of date palm $\mathrm{cv}$. Bartamouda. The results revealed that Drosera capensis root extract had a significant effect on fresh weight of date palm embryogeneic callus as the best result $(4.63 \mathrm{~g})$ was observed with using Drosera capensis root extract at $3.0 \mathrm{ml} \mathrm{L}$. Using of Drosera capensis root extract at $0.05 \mathrm{ml} \mathrm{L}^{-1}$ gave rise to higher number of mature embryos. The highest significant shoot number (21 shoots) of date palm was obtained with using $1.0 \mathrm{ml} \mathrm{L}^{-1}$ Drosera capensis leaf extract. Also the length of date palm shoots 
increased significantly by using the same concentration of Drosera capensis leaf extract and reached $3.3 \mathrm{~cm}$.

Finally, in-vitro date palm cultivation can be achieved with MS medium supplemented with Drosera capensis extract as a source of phytohormones at different micropropagation stages.

Key words: Drosera capensis extract,Phytohormones, In-vitro, date palm $c v$. Bartamouda, Embryogeneic calli, Mature embryos, Shoot formation.

\section{INTRODUCTION}

The in-vitro growth and development of a plant is determined by a number of complex factors: The genetic make-up of the plant; Physical growth factors (Light -Temperature - $\mathrm{CO} 2-\mathrm{pH}$ ); Nutrients: water, macro and micro elements and sugars and some organic substances (plant growth regulators, vitamins, amino acids). Media used in tissue culture are composed of a high number of ingredients such as macro and micro-nutrient salts, plant-growth regulators, amino acids, vitamins, sugar, gelling agents and activated charcoal (Pireik, 1987). Most of this compounds are expensive especially plant growth regulators, so some workers tried to use naturalorganic products as a substitute to these ingredients. Hassan et al. (2008) reported that Pollen extracts of date palm were used in tissue culture medium for banana as growth substances in comparison with growth regulators. Most of treated plants showed highly growth characteristics such as shoot number, shoot length, root number, root length, fresh weight and dry weight compared to either the cytokinin (Benzyl Adenine) and/or the auxin (Indole Butyric Acid and Naphthalene Acetic Acid). El-Assar et al. (2004) studied the effects of natural extract Date Palm meristimatic tissue on length, diameter, and color of "Sewi" apical tip growing tissues. They found that the extract of date palm meristimatic tissue produced significant increasing of growing tissues. The carnivorous-medicinal plant Drosera capensis (Cape Sundew) contains many of important substances that have a huge economic importance because their useful effect in agriculture and drug manufacture to cure many diseases (Roberto (1984); Bunney (1992); Marczak et al. (2005); Jindaprasert et al. (2008)).

Date palm (Phoenix dactylifera L.), a monocotyledonous and dioecious species belonging to the Arecaceae family, is widely cultivated in arid regions of the Middle East and North Africa (Al-Khayri, 2001) and it needs especial media through its micropropagation. This study aimed to evaluate the Drosera capensis content from phyto-hormones and using its 
plant extract, as a source of plant growth regulators containing MS medium, on in-vitro growth and development of date palm (Phoenix dactylifera $\mathrm{cv}$ Bartamouda).

\section{MATERIALS AND METHODS}

This study was conducted at the Central Laboratory of Development of Date Palm Research, Agricultural Research Center, Giza, Egypt and Genetic Engineering and Biotechnology Research Institute (GEBRI), Minufiya University, Sadat city during the period from 2006 to 2010.

In-vitro Cultures of Drosera capensis plants were established on half strength of MS (Murashige and Skoog, 1962) basal medium according to the method described by Shams El-Din (2002). In-vitro shoots were multiplied for six subcultures and transferred to rooting stage. Plantlets produced from rooting stage were subjected for extraction of samples then separated with HPLC. Drosera capensis extraction from leaves and roots were used as a source of plant growth regulators to in-vitro propagation of date palm cv. Bartamouda.

Acidic plant hormones, indole acetic acid (IAA), gibberellic acid $\left(\mathrm{GA}_{3}\right)$ and absisic acid (ABA) and cytokinins were extracted from Drosera capensis plants ( leaves and roots ) and determined according to the method described by Shindy and Smith (1975) using high performance liquid chromatography (HPLC) at Arid Land Agricultural Research Unit, Faculty of Agriculture, Ain Shams University.

\section{Micropropagation of date palm using Drosera capensis extract:}

Forty grams fresh weight of Drosera capensis leaves or sixty grams of roots (in-vitro) were extracted with $100 \mathrm{ml}$ of ethyl alcohol $95 \%$ at room temperature for three days. The extract was filtered and the solvent removed at low temperature $\left(35-40{ }^{\circ} \mathrm{C}\right)$ and reduced pressure on a rotary evaporator. The residue was re-dissolved in two $\mathrm{ml}$ ethanol $95 \%$ and completed to $10 \mathrm{ml}$ by sterilized water. This final solution was subjected to use in experiments of date palm. Whereas the both extract of leaves and roots were filter sterilized and added to sterilized culture medium of date palm (Tisserat, 1981; Ibrahim and Hegazy, 2001 and Hegazy et al.2009).

\section{The effect of $\underline{\text { Drosera }} \underline{\text { capensis }}$ root extract on production of embryogeneic callus:}

Callus formation of date palm cv. Bartamouda was obtained from date palm offshoots (from Aswan governorate) according the method described by Ibrahim et al. (2008) and Hegazy et al. (2009). 
In this experiment the Embryogeneic calli resulted from previous invitro cultures were divided into pieces of approximately $0.5 \mathrm{~g}$ and cultured on $3 / 4 \mathrm{MS}$ medium supplemented with $200 \mathrm{mgL}^{-1} \mathrm{KH}_{2} \mathrm{PO}_{4} \cdot 2 \mathrm{H}_{2} 0,170 \mathrm{mg} \mathrm{L}^{-1}$ $\mathrm{NaH}_{2} \mathrm{PO}_{4} \cdot 2 \mathrm{H}_{2} 0,200 \mathrm{mg} \mathrm{L}^{-1}$ glutamine, $100 \mathrm{mg} \mathrm{L}^{-1}$ myo-inositol, $1.0 \mathrm{~g} \mathrm{~L}^{-1}$ activated charcoal, $40 \mathrm{~g} \mathrm{~L}^{-1}$ sucrose, $5 \mathrm{~g} \mathrm{~L}^{-1}$ Bacteriological agar and different amounts of Drosera capensis root extract was added at $0,0.75,1.5,3.0$ or $6.0 \mathrm{ml} \mathrm{L}^{-1}$, without plant growth regulators. While the control contained 2,4$\mathrm{D}$ at $0.5 \mathrm{mg} \mathrm{L}^{-1}$ and Kinetin at $1.0 \mathrm{mg} \mathrm{L}^{-1}$ and Medium $\mathrm{pH}$ was adjusted to 5.8 (Gadalla, 2007). Each treatment included three replicates (12 small jars $(200 \mathrm{ml})$ contained $35 \mathrm{ml}$ of nutrient MS medium). Each jar contained about $(0.5 \mathrm{~g})$ embryogeneic callus. All cultures were incubated in total darkness, $25 \pm 2^{\circ} \mathrm{C}$. The fresh weight of embryogeneic calli were recorded after four, eight and 12 weeks from onset of the culture.

\section{The effect of Drosera capensis root extract on Maturation stage:}

Embryogeneic calli resulted from previous stage were divided into pieces of approximately $\left(1 \mathrm{~cm}^{2}\right)$ and cultured on $3 / 4 \quad \mathrm{MS}$ medium supplemented with Drosera capensis root extract at $0,0.05,0.1,0.2$ or 0.4 $\mathrm{ml} \mathrm{L} \mathrm{L}^{-1}$, while the control medium which was contained NAA at $0.1 \mathrm{mg} \mathrm{L}^{-1}$. Each treatment included three replicates (12 small jars). Each jar contained about $\left(1 \mathrm{~cm}^{2}\right)$ embryogeneic callus. All cultures were incubated in 500-1000 Lux at $16 \mathrm{hrs}, 25 \pm 2^{\circ} \mathrm{C}$ for 12 weeks (4 weeks interval). The number of mature embryos recorded after four, eight and 12 weeks from onset of the culture.

\section{The effect of Drosera capensis leaf extract on Shoot formation stage:}

The mature embryos resulted from previous stage were germinated on $3 / 4$ MS medium free from plant growth regulators and were cultured (cluster contained from three to four embryos per jar) for four weeks and then cultures were transferred to $3 / 4 \mathrm{MS}$ medium supplemented with $30 \mathrm{~g} \mathrm{~L}^{-1}$ sucrose, $5 \mathrm{~g} \mathrm{~L}^{-1}$ Bacteriological agar, $0.5 \mathrm{~g} \mathrm{~L}^{-1}$ activated charcoal and $0.5 \mathrm{mg}$ $\mathrm{L}^{-1} \mathrm{BA}$ plus $0.1 \mathrm{mg} \mathrm{L}^{-1} \mathrm{NAA}$ as a control and five concentrations of Drosera capensis leaf extract at $0.0,0.25,0.5,1.0$, and $2.0 \mathrm{ml} \mathrm{L}^{-1}$ in three replicates each replicate contains four jars. All cultures were incubated in $3000 \mathrm{Lux}$ at $16 \mathrm{hrs}, 25 \pm 2{ }^{\circ} \mathrm{C}$. These cultures were transferred into the same fresh medium every four weeks. After four, eight and 12 weeks shoot number and shoot length $(\mathrm{cm})$ were recorded. The best date palm shoots $(6-8 \mathrm{~cm}$ length) were transferred to date palm rooting medium for 4.5 months through three recultures and subsequently to adaptation stage in greenhouse (Gadalla, 2007). Data obtained were subjected to the analysis of variances of randomized complete design as recommended by Sendecor and Cochran (1980). 


\section{RESULTS AND DISCUSSION}

Qualitative and quantitative analysis of phytohormones by high performance liquid chromatography (HPLC):

Data presented in Table (1) reveal that the amounts of phytohormones (mg $100 \mathrm{~g}^{-1}$ fresh weight) in Drosera capensis leaf and root extract are differing. The amount of Indole acetic acid in leaf was 2.055, but in case of root was 2.291. The amount of zeatine in leaf was 1.609 , but in case of root was 0.418 . The amount of other cytokinines in leaf was 18.791 , but in case of root was 1.003 .

Table 1. The amount of phytohormones in leaf and root of in-vitro Drosera capensis (mg $\mathbf{~}^{-100 \mathrm{~g}^{-1}}$ fresh weight)

\begin{tabular}{lcc}
\hline Type of Hormone & Leaf & Root \\
\hline Indole acetic acid & 2.055 & 2.291 \\
Zeatine & 1.609 & 0.418 \\
Substances-like Cytokinines & 18.791 & 1.003 \\
Gibberellic acid & 70.938 & 86.59 \\
Abscissic acid & 0.500 & 0.158 \\
\hline
\end{tabular}

The amount of gibberellic acid in leaf was 70.938, but in case of root were 86.59. The amount of abscissic acid in leaf was 0.500 , but in case of root was 0.158 . These results coincided with many researchers such as Straus (1960); Steinhart et al. (1961); Roberto (1984) and Puchooa and Ramburn (2004).

\section{Effect of Drosera capensis root extract concentration on fresh weight (g) of embryogeneic callus of date palm cv. Bartamouda:}

Data in Table (2) show that Drosera capensis root extract concentration had a significant effect on fresh weight of embryogeneic callus of date palm cv. Bartamouda. In case of using 2,4-D at $0.5 \mathrm{mg} \mathrm{L}^{-1}$ with $1 \mathrm{mg} \mathrm{L}^{-1}$ Kinetin, treatment No. (1), as a control to compare with Drosera capensis root extract concentrations at 0.0, 0,75, 1,5, 3,0 and 6,0 $\mathrm{ml}$ $\mathrm{L}^{-1}$, it was found that the effect of control somewhat equal to the effect of Drosera capensis root extract at $6.0 \mathrm{ml} \mathrm{L}^{-1}$, whereas there is no a significant different between them. Where, the fresh weight of embryogenic callus at treatment No. (1) reached to (1.57), (2.90) and (4.13) g after four, eight and 12 weeks, respectively. While in case of Drosera capensis root extract at 6.0 
Table 2. Effect of Drosera capensis root extract concentration on fresh weight (g) of embryogeneic callus of date palm cv. Bartamouda.

\begin{tabular}{|c|c|c|c|c|}
\hline \multicolumn{2}{|r|}{ Treatments } & \multicolumn{3}{|c|}{ Fresh weight (g), after } \\
\hline $\begin{array}{c}\text { No. of } \\
\text { Treatment }\end{array}$ & Concentration & $\begin{array}{c}4 \\
\text { weeks }\end{array}$ & $\begin{array}{c}8 \\
\text { weeks }\end{array}$ & $\begin{array}{c}12 \\
\text { weeks }\end{array}$ \\
\hline 1 & $0.5 \mathrm{mg} \mathrm{L}^{-1} 2,4-\mathrm{D}+1 \mathrm{mg} \mathrm{L}^{-1}$ Kinetin & 1.57 & 2.90 & 4.13 \\
\hline 2 & $0.0 \mathrm{ml} \mathrm{L}{ }^{-1}$ Drosera capensis root extract & 0.77 & 0.93 & 1.10 \\
\hline 3 & $0.75 \mathrm{ml} \mathrm{L}^{-1}$ Drosera capensis root & 0.83 & 1.13 & 2.03 \\
\hline 4 & $1.5 \mathrm{ml} \mathrm{L}^{-1}$ Drosera capensis root extract & 1.23 & 2.47 & 3.57 \\
\hline 5 & $3.0 \mathrm{ml} \mathrm{L}^{-1}$ Drosera capensis root extract & 1.6 & 3.20 & 4.63 \\
\hline 6 & $6.0 \mathrm{ml} \mathrm{L}^{-1}$ Drosera capensis root extract & 1.47 & 2.83 & 4.10 \\
\hline \multicolumn{2}{|c|}{ L S D at 0.05} & 0.13 & 0.15 & 0.21 \\
\hline
\end{tabular}

$\mathrm{mg} \mathrm{L}^{-1}$ were $1.47,2.83$ and $4.10 \mathrm{~g}$ after four, eight and 12 weeks, respectively. But the best result was obtained with the use of Drosera capensis root extract at $3,0 \mathrm{mg} \mathrm{L}^{-1}$ where this character reached its utmost, 1.6, 3.2 and $4.63 \mathrm{~g}$ after four, eight and 12 weeks, respectively. In-general the effect of Drosera capensis root extract had a stimulatory effect on fresh weight of embryogeneic callus at lowest consentrations, but at highest concentrations it had inhabitor effect. Whereas fresh weight of embryogeneic callus increased gradually and significantly, except treatments No. 2 and 3 after four weeks, as Drosera capensis root extract concentration increased from 0.00 to $0.75,1,5$ and $3,0 \mathrm{ml} \mathrm{L}^{-1}$ where this character increased from $0.77,0.93$ and $1.10 \mathrm{~g}$ after four, eight and 12 weeks, respectively to 0.83 , 1.13 and $2.03 \mathrm{~g}$ after four, eight and 12 weeks, respectively, (1.23), (2.47) and (3.57) $\mathrm{g}$ after four, eight and 12 weeks, respectively and 1.6, 3.2and $4.63 \mathrm{~g}$ after four, eight and 12 weeks, respectively.

Raising Drosera capensis root extract concentration to $6.0 \mathrm{ml} \mathrm{L}^{-1}$ affected fresh weight of embryogeneic callus inversely, as it declined to $1.47,2.83$ and (4.10) $\mathrm{g}$ after four, eight and 12 weeks, respectively. In this concern, it has been reported that in many plant species adding of plant extracts juice of coconut, tomato, potato, onion, banana, orange, apple, pineapple, and yeast to the culture medium enhanced the growth of tissues. Hassan et al. (2008) reported that pollen extracts of date palm were used in tissue culture medium for banana as growth substances in comparison with growth regulators. Most of treated plants showed highly growth characteristics such as fresh weight compared to either the cytokinin (benzyl adenine) and/or the auxin (indole butyric acid and naphthalene acetic acid). 
Effect of Drosera capensis root extract concentration on number of mature embryos of Date Palm cv. Bartamouda in production of embryos :

Data in Table (3) show that Drosera capensis root extract concentration had a significant effect on number of mature embryos of Date Palm cv. Bartamouda in production of embryos stage after 12 weeks. Whereas in case of using Drosera capensis root extract at $0.05 \mathrm{ml} \mathrm{L}^{-1}$ the number of mature embryos reached to the highest record 12.7 compared with media free Drosera capensis root extract 6.3 , and also the medium which containing NAA at $0.1 \mathrm{mg} \mathrm{L}^{-1}$ where the number of mature embryos was 10.3. The effects of using plant extracts in in-vitro culture have been investigated by a number of workers. One of the earliest report is that of Overbeek et al. (1941), who succeeded in growing immature Datura embryos in culture by including the liquid endosperm of Cocos nucifera (coconut milk) in their culture medium.

Table 3. Effect of Drosera capensis root extract concentration on number of mature embryos of Date Palm cv. Bartamouda in production of embryos stage

\begin{tabular}{ccccc}
\hline & Treatments & \multicolumn{3}{c}{ No. of mature embryos, } \\
\hline $\begin{array}{c}\text { No. of } \\
\text { treatment }\end{array}$ & Concentration & $\begin{array}{c}\mathbf{4} \\
\text { weeks }\end{array}$ & $\begin{array}{c}\mathbf{8} \\
\text { weeks }\end{array}$ & $\begin{array}{c}\mathbf{1 2} \\
\text { weeks }\end{array}$ \\
\hline $\mathbf{1}$ & $0.1 \mathrm{mg} \mathrm{L}^{-1} \mathrm{NAA}$ & 7 & 9 & 10.3 \\
$\mathbf{2}$ & $0.0 \mathrm{mg} \mathrm{L}^{-1}$ Drosera capensis root & 4.3 & 5.3 & 6.3 \\
$\mathbf{3}$ & $0.05 \mathrm{ml} \mathrm{L}^{-1}$ Drosera capensis root & 9 & 11 & 12.7 \\
$\mathbf{4}$ & $0.1 \mathrm{ml} \mathrm{L}^{-1}$ Drosera capensis root & 8.3 & 10 & 12.0 \\
$\mathbf{5}$ & $0.2 \mathrm{ml} \mathrm{L}^{-1}$ Drosera capensis root & 6.3 & 8.3 & 9.8 \\
$\mathbf{6}$ & $0.4 \mathrm{ml} \mathrm{L}^{-1}$ Drosera capensis root & 5 & 6.3 & 7.5 \\
\hline L S D at $\mathbf{0 . 0 5}$ & & $\mathbf{2 . 1}$ & $\mathbf{1 . 1}$ & $\mathbf{1 . 0}$ \\
\hline
\end{tabular}

Effect of Drosera capensis leaf extract concentration on shoot formation of Date Palm cv. Bartamouda:

Data presented in Tables (4 and 5) show the effect of Drosera capensis leaf extract concentration on shoot formation estimated as shoot number and shoot length $(\mathrm{cm})$ of Date Palm cv. Bartamouda: It's notced that when the Drosera capensis leaf extract concentration increased from 0.0 to $0.25,0.5$ and $1.0 \mathrm{ml} \mathrm{L}^{-1}$ the number of shoots increased significantly from 5.7, 7, and 7.7 to 7.3, 9.7 and 10.3, 9.7, 11.7 and 13.3 and 15.3, 17.3 and 21 after 4, 8 and 12 weeks respectively. But when Drosera capensis leaf extract increased to $2.0 \mathrm{ml} \mathrm{L}^{-1}$ the number of shoots decreased significantly to 13.3 , 
Table 4. Effect of Drosera capensis leaf extract concentration on Shoot Number of Date Palm cv. Bartamouda in shoot formation stage

\begin{tabular}{|c|c|c|c|c|}
\hline \multicolumn{2}{|r|}{ Treatments } & \multicolumn{3}{|c|}{ Shoot Number, after } \\
\hline $\begin{array}{c}\text { No. of } \\
\text { Treatment }\end{array}$ & Concentration & $\begin{array}{c}4 \\
\text { weeks } \\
\end{array}$ & $\begin{array}{c}8 \\
\text { weeks } \\
\end{array}$ & $\begin{array}{c}12 \\
\text { weeks }\end{array}$ \\
\hline 1 & $0.1 \mathrm{mg} \mathrm{L}^{-1} \mathrm{NAA}$ and $0.5 \mathrm{mg} \mathrm{L}^{-1} \mathrm{BA}$ & 13.3 & & 16.3 \\
\hline 2 & $0.0 \mathrm{ml} \mathrm{L}{ }^{-1}$ Drosera capensis leaf & 5.7 & 7.0 & 7.7 \\
\hline 3 & $0.25 \mathrm{ml} \mathrm{L}^{-1}$ Drosera capensis leaf & 7.3 & 9.7 & 10.3 \\
\hline 4 & $0.5 \mathrm{ml} \mathrm{L}^{-1}$ Drosera capensis leaf & 9.7 & 11.7 & 13.3 \\
\hline 5 & $1.0 \mathrm{ml} \mathrm{L}^{-1}$ Drosera capensis leaf & 15.3 & 17.3 & 21 \\
\hline 6 & $2.0 \mathrm{ml} \mathrm{L}^{-1}$ Drosera capensis leaf & 13.3 & 15 & 17 \\
\hline \multicolumn{2}{|l|}{$\bar{L}$ S D at 0.05} & 1.1 & 0.9 & 0.7 \\
\hline
\end{tabular}

15 and 17 after 4,8 and 12 weeks respectively. While in case of medium containing NAA at $0.1 \mathrm{mg} \mathrm{L}^{-1}$ plus BA at $0.5 \mathrm{mg} \mathrm{L}^{-1}$ the shoots number were $13.3,14.7$ and 16.3 after 4,8 and 12 weeks respectively. These results are in agreement with that of Henderson et al., 1952 and Archibald, 1954 they reported that coconut milk was shown to stimulate cell division in cultured tissues and its use as a supplement was adopted in many laboratories. Al-khateeb (2008) studied the effect of date syrup concentration on in-vitro multiplication of date palm cv. Rhanezi. He found that lower concentration of date palm syrup 5\% has successfully induced buds and shoots formation.

\section{Effect of Drosera capensis leaf extract concentration on shoot length of date palm cv. Bartamouda:}

Data in Table (5) show that, shoot length of date palm was affected significantly by Drosera capensis leaf extract.

The highest records of this character was $2.77 \mathrm{~cm} ., 3.07$ and $3.3 \mathrm{~cm}$ after 4,8 and 12 weeks respectively at $1.0 \mathrm{ml} \mathrm{L}^{-1}$ Drosera capensis leaf extract followed by $2.5,2.7$ and 2.9 after 4,8 and 12 weeks respectively at $2.0 \mathrm{ml} \mathrm{L}^{-1}$ followed by $2.27,2.47$ and 2.8 after 4,8 and 12 weeks respectively at $0.5 \mathrm{ml} \mathrm{L}^{-1}$, also these records were at using combination of NAA at $0.1 \mathrm{mg} \mathrm{L}^{-1}$ and $0.5 \mathrm{mg} \mathrm{L}^{-1}$ BA. While using Drosera capensis leaf extract at $0.25 \mathrm{ml} \mathrm{L}^{-1}$ the shoot length was 2.1, 2.2 and 2.4 after 4, 8 and 12 weeks respectively. Also using medium free of Drosera capensis leaf extract showed shoots of 2.07, 2.17 and 2.4 in length after 4,8 and 12 weeks respectively. It was noticed that no significant differences between the use of Drosera capensis leaf extract at 0.0 and $0.25 \mathrm{ml} \mathrm{L}^{-1}$. 
Table 5. Effect of Drosera capensis leaf extract concentration on Shoot Length $(\mathrm{cm})$ of Date Palm cv. Bartamouda in shoot formation stage:

\begin{tabular}{clccc}
\hline & Treatments & \multicolumn{3}{c}{ Shoot Length (cm), after } \\
\hline No. of & Concentration & $\begin{array}{c}\mathbf{4} \\
\text { weeks }\end{array}$ & $\begin{array}{c}\mathbf{8} \\
\text { weeks }\end{array}$ & $\begin{array}{c}\mathbf{1 2} \\
\text { weeks }\end{array}$ \\
treatment & & & & \\
\hline $\mathbf{1}$ & & & & \\
$\mathbf{2}$ & $0.1 \mathrm{mg} \mathrm{L}^{-1}$ NAA and $0.5 \mathrm{mg} \mathrm{L}^{-1} \mathrm{BA}$ & 2.27 & 2.47 & 2.8 \\
$\mathbf{3}$ & $0.0 \mathrm{ml} \mathrm{L}^{-1}$ Drosera capensis leaf & 2.07 & 2.17 & 2.4 \\
$\mathbf{4}$ & $0.5 \mathrm{ml} \mathrm{L}^{-1}$ Drosera capensis leaf & 2.1 & 2.2 & 2.4 \\
$\mathbf{5}$ & $1.0 \mathrm{ml} \mathrm{L}^{-1}$ Drosera capensis leaf & 2.27 & 2.47 & 2.8 \\
$\mathbf{6}$ & $2.0 \mathrm{ml} \mathrm{L}^{-1}$ Drosera capensis leaf & 2.77 & 3.07 & 3.3 \\
\hline $\mathbf{L} \mathbf{D}$ at $\mathbf{0 . 0 5}$ & & 2.5 & 2.7 & 2.9 \\
\hline
\end{tabular}

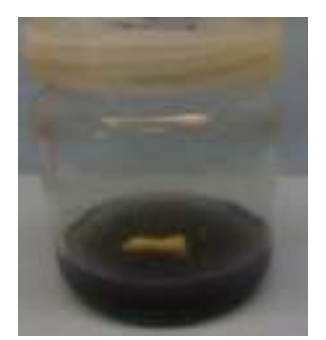

Starting stage $3 / 4 \mathrm{MS}+100 \mathrm{mg}$ $\mathrm{L}^{-1} 2,4-\mathrm{D}+3$ mg L $^{-1}$ 2-ip

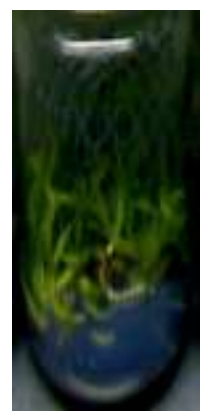

Shooting $3 / 4 \mathrm{MS}+1.0 \mathrm{ml}$ $\mathbf{L}^{-1}$ Drosera capensis leaf extract

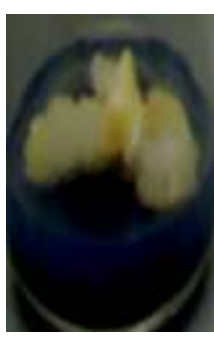

Swelling $3 / 4 \mathrm{MS}+10 \mathrm{mg}$ $\mathrm{L}^{-1}$ 2, 4-D +3 $\mathrm{mg} \mathrm{L}^{-1}$ 2-ip

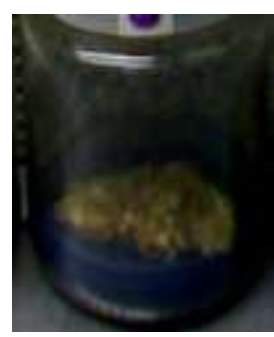

Embryogeneic callus $3 / 4$ MS + 3.0 ml L ${ }^{-1}$ Drosera capensis root extract

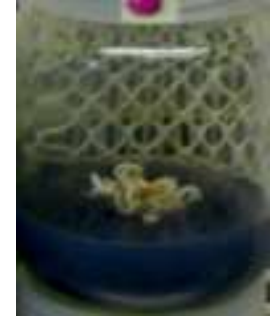

Somatic embryos $3 / 4 \mathrm{MS}+\mathbf{0 . 0 5} \mathrm{ml}$ $\mathbf{L}^{-1}$ Drosera capensis root extract

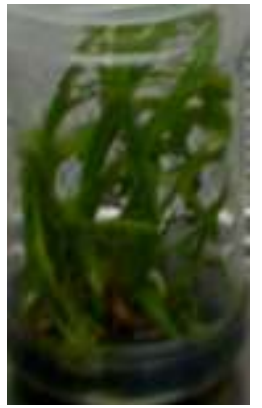

Elongation $1.0 \mathrm{ml} \mathrm{L}^{-1}$ Drosera capensis leaf extract

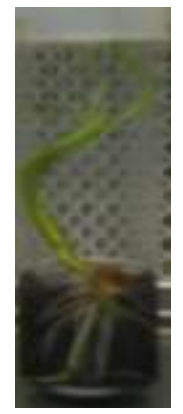

Rooting $3 / 4 \mathrm{MS}+1.0 \mathrm{ml}$ $\mathrm{L}^{-1}$ Drosera capensis root extract

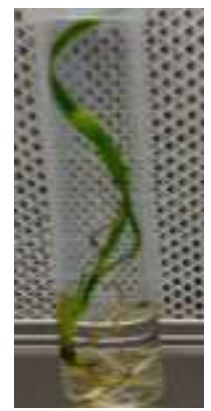

Preacclimatization $1.0 \mathrm{ml} \mathrm{L}^{-1}$ Drosera capensis root extract

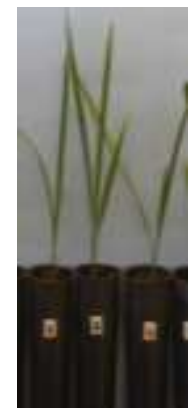

Acclimatization $1.0 \mathrm{ml} \mathrm{L}^{-1}$ Drosera capensis root extract

In-vitro propagation of date palm using Drosera capensis extract. 
In this Concern, Hassan et al. (2008) reported that Pollen extracts of date palm were used in tissue culture medium for banana as growth substances in comparison with growth regulators. Most of treated plants showed highly growth characteristics such as shoot number, shoot length compared to either the cytokinin (benzyl adenine) and/or the auxin (indole butyric acid and naphthalene acetic acid). In conclusion, natural extract such as pollen extract of date palm provided to be an excellent economic resources as growth substances.

The results of shoot proliferation and elongation response to different concentrations of BA as control, water pollen extract or ethanol pollen extract revealed that pollen extracts succeeded as plant growth substances instead of cytokinins at shoot multiplication stage of banana tissue culture.

Conclusively, results of this study indicated that. Micropropagation of date palm can be achieved using MS medium supplementrd with extaract of Drosera capenses as a source of phytohormones at the dufferent micropropagation stages. Extract of Drosera capensis showed a significant effect on fresh weight of embryogenic callus, and the same extract at 0.05 $\mathrm{mg} / \mathrm{l}$ observed the highest number of mature embryos. Moreover, the extract of leaves at $1 \mathrm{mg} / \mathrm{l}$ gave the highest shoot number and length.

\section{REFERENCES}

Al-khateeb, A. A. (2008). Enhancing the growth of Date palm (Phoenix dactylifera) in-vitro tissue by adding date syrup to the culture medium. Scientific Journal of King Faisal University (Basic and Applied Sciences).9 (1): 71-84.

Al-Khayri, J. M. (2001). Optimization of biotin and thiamine requirements for somatic embryogenesis of date palm (Phoenix dactylifera $\mathrm{L}$.). IN VITRO CELL. DEV. BIOL. PLANT, 37:453-456.

Archibald, J. F. (1954). Culture in-vitro of cambial tissues of cacao. Nature, 173: 351-353.

Bunney, S. (1992). The Illustrated Encyclopedia Of Herbs Their Medicinal And Culinary Uses. Chancellor press, Michelin House, London PP.:138.

El-Assar, A. M.; El-Messeih, W. M. and El-Shenawi, M. R. (2004). Applying of some natural extracts and growth regulators to culture media and their effects on "Sewi" cv. Date palm tissues grown invitro. Assiut Journal of Agricultural Sciences, 35(4): 155-168. 
Gadalla, E. (2007). High frequency somatic embryo production and maturation into plantlets in date palm (phoenlx dactylifera L.) Through suspension culture. Egyptian Journal of Agriculture Research, 85 (1): 349- 365.

Hassan, H. M. M.; Ahmed, O.K.; El-Shemy, H.A. and Afify, A.S. (2008). Palm pollen extracts as plant growth substances for Banana tissue culture. World Journal of Agricultural Sciences, 4 (4): 514-520.

Hegazy, A. E.; Nasr M. I.; Ibrahim I. A. and El-Bastawissy H. H. (2009). Micropropagation of date palm cv. Malakaby through embryogenesis: 2- Effect of adenine hemisulfate, glutamine and glutathione. Journal of Agri. Sci., Mansoura Univ., 34 (3): 15451560 .

Henderson, J.H.M.; Durrell, M.E. and Bonner, J. (1952). The cultures of normal sunflower callus. Am. J. Bot., 39: 467-472.

Ibrahim, I. A.; Gabr,M.F.; Nasr , M.I. and Fadl,R.A.(2008). Effect of cobalt chloride on somatic embryogenesis of Egyptian dry date palm cultivars. $1^{\text {st }}$ International Conference on Environmental Studies and Research, Environmental Studies and Research Institute (ESRI), Minufiya University- Sadat Branch, April 2008.

Ibrahim, I.A. and Hegazy, A.E. (2001). In-vitro cultivation of date palm. 3- Date palm abnormalities during micropropagation via embryogenesis. Mid-Atlantic Plant Molecular Biology Society, Eighteenth Annual Meeting, 2, Beltisville-MD, USA, August 2-3, $2001 \mathrm{p} 39$.

Jindaprasert, A.; Springob, K.; Schmidt, J.; De-Eknamkul, W. and Kutchan T. M. (2008). Pyrone polyketides synthesized by a type III polyketide synthase from Drosophyllum lusitanicum. Photochemistry, 69 (18): 3043-3053.

Marczak, L.; Kawiak, A.; Lojkowska E. and Stobiecki M. (2005). Secondary metabolites in in-vitro cultured plants of the genus Drosera.Phytochem Anal., 16(3):143-149.

Murashige, T. and Skoog, F. (1962). A revised medium for rapid growth and bioossays with tobacco tissue cultures. Physiol. Plant., 15: 473- 497.

Overbeek, J.V.; Conklin, M.E. and Blakeslee, A.F. (1941). Factors in coconut milk essential for growth and development of very young Datura embryos. Science, 94: 350-352.

Pierik, R.L.M.( 1987). Preparation and composition of nutrient media. In: In Vitro Culture of Higher Plants. Martinus Nijhoff, Dordrecht, 45-82p. 
Puchooa, D. and Ramburn, R.(2004). A study on the use of carrot juice in the tissue culture of Daucus carota. African Journal of Biotechnology, 3 (4): 248-252.

Roberto, C. (1984). Encyclopedia of Medicinal Plants, The Macdonald, Maxwell House, London, Number 117.

Snedecor, G.W. and Cochran, W. G. (1980). Statistical Methods. $6^{\text {th }}$ ed., Iowa state University Press, Iowa, USA.

Shams El-Din, I. M. (2002). Evaluation of some species of insectivorous plants and their propagation through tissue culture. Department of Agricultural Science. Institute of Environmental Studies and Research. Ain Shams University.

Shindy, W.W. and Smith, O. (1975). Identification of plant hormones from cotton ovules. Plant Physiol., 55: 550-554

Steinhart, C.E.; Standifer, L.G. and Skoog, F. (1961). Nutrient requirements for in vitro growth of spruce tissue. Am. J. Bot., 48: 465-472.

Straus, J. (1960). Maize endosperm tissue grown in vitro : Development of a synthetic medium. Am. J. Bot. , 47: 641-646.

Tisserat, B. (1981). Date palm tissue culture. Advances-in-AgriculturalTechnology,-Western-Series,-United States Department of Agriculture, (17): 50. 


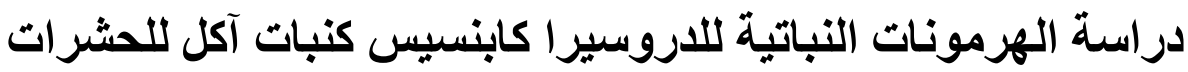

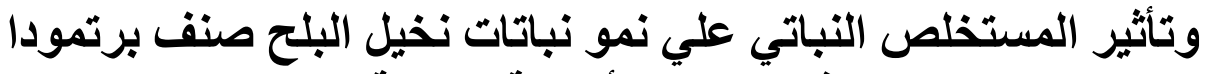
في مزارع الأنسجة النباتية نياتئ

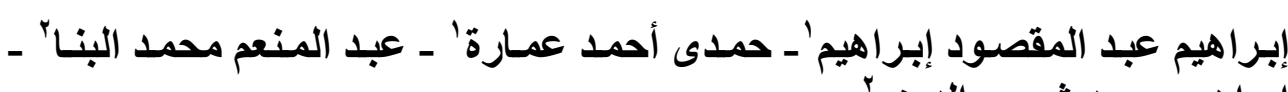

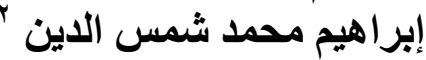
1 ـ قسم التكنولوجيا الحيوية النباتية، معهد الهندسة الو ر اثثية و التكنولوجيا الحيوية،

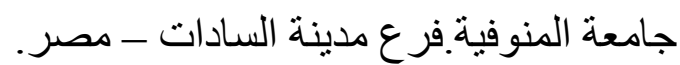

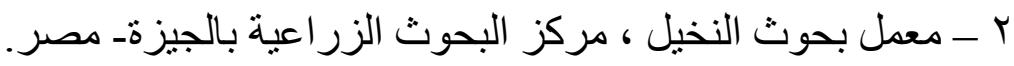

تنتمي النباتات آكلة الحشر ات لعدة عائلات نباتية أهمها العائلة الدروسيرية التي ينتمي إليها

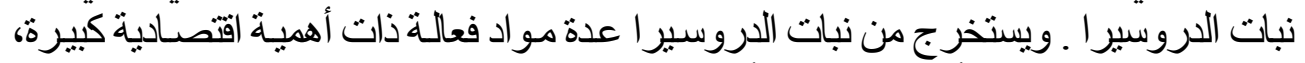

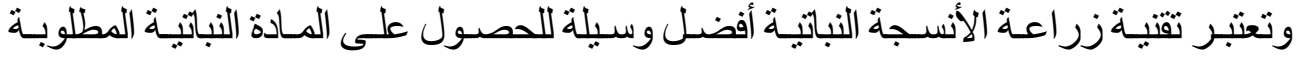
للحصول على المواد الفعالة التي بها التها. تهوف هذه الدراسة إلى عمل دراسات فيتو كيميائية علي نبات دروسير الكابنسيس لمعرفة

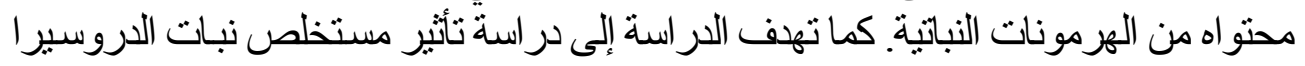

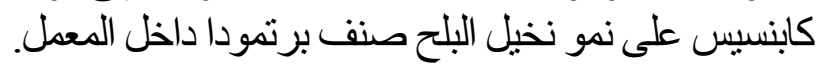

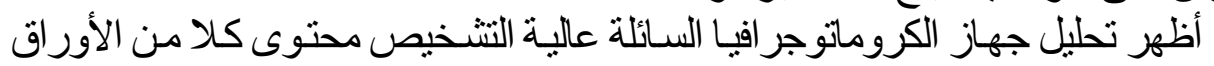

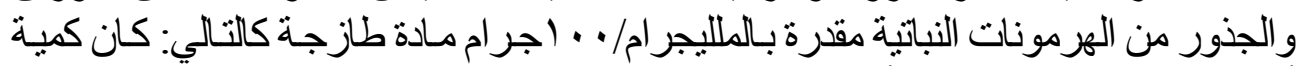

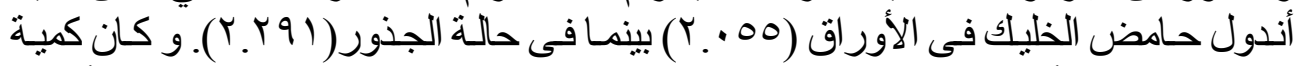

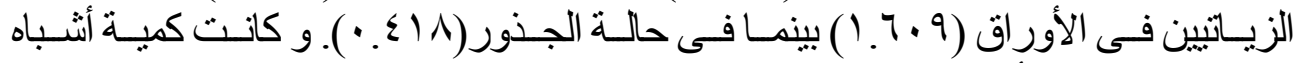

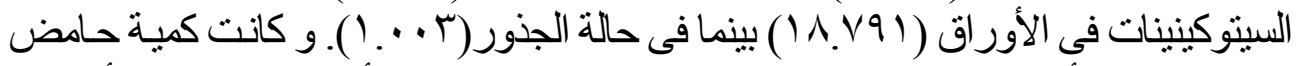

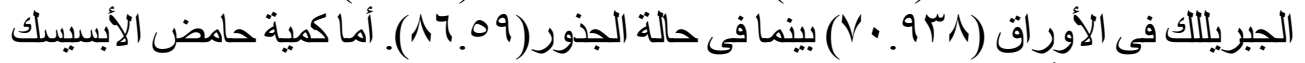

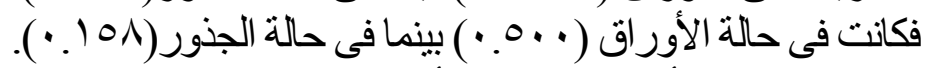

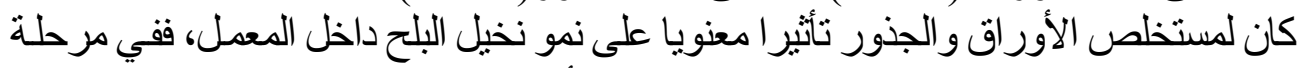

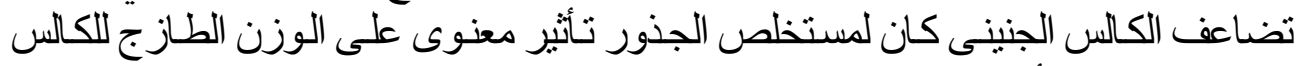

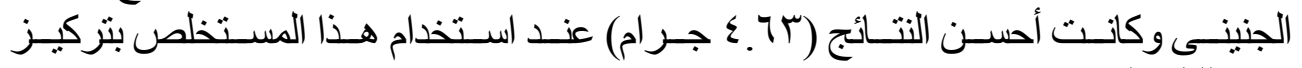

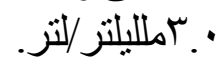

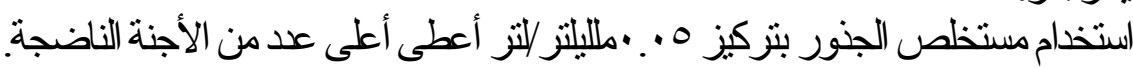

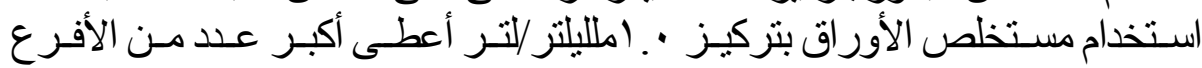

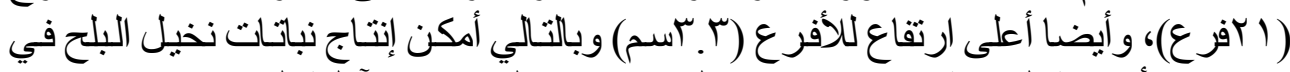

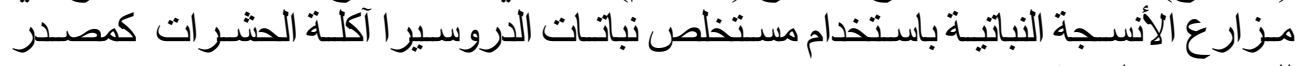

